\title{
Most Common Fungal Diseases of Globe Artichoke (Cynara scolymus L.) Production Areas
}

\author{
Aysegul Colak Ates \\ Biological Control Research Institute, Department of Phytopathology, \\ Kisla St. 01321 Yuregir, Adana, Turkey \\ E-mal: aysegulcolak@hotmail.com
}

\begin{abstract}
Globe Artichoke is an important export product after the potatoes and citrus fruits in Turkish Republic of Nothern Cyprus. Due to the fact that climatic conditions are very suitable for globe artichoke cultivation in the country, globe artichoke production area reached 5.622 da and were obtained 12 tons of products in 2016. Globe artichoke production is made of $66 \%$ in Gazimağusa Region and this followed by $15 \%$ in Güzelyurt Region, $11 \%$ in Iskele Region and $8 \%$ in Lefkoşa Region. Some diseases and pests that restrict globe artichoke cultivation reduce the market value in addition to the advantages of earlyness in production. White mold (Sclerotinia sclerotiorum) disease was detected in 32 locations from the most intensive fungal diseases in simptomatological and morphological analyzes made from plant samples taken from globe artichoke cultivation in 79 locations between 2011-2015. In 444.20 da surveyed area, $67.10 \%$ of the globe artichoke locations were found to be infected with pathogenic fungal disease. In the study, in the areas where globe artichoke cultivation is carried out, soil-borne pathogens Sclerotinia sclerotiorum, Botrytis cinerea, Macrophomina phaseolina and Fusarium spp. fungal diseases have been identified. The results of this study are important in determining an effective control method with the detection of fungal diseases that affect globe artichoke production and quality in the region.
\end{abstract}

Keywords: Globe artichoke, Northern Cyprus, plant disease

DOI: $10.7176 / J S T R / 6-04-07$

\section{Introduction}

Globe artichoke (Cynara scolymus L.) is a family of Asteraceae, its underground stem is a perennial, and its above-ground organs are one-year-old vegetable species. Artichoke is a very valuable vegetable known since the ancient Greeks and Romans (Nermien et al., 2019; Bektaş and Saner, 2013). In addition to its fresh consumption, it is used in canned food and frozen food. The edible part of the artichoke is the wide and fleshy flower tray of the unopened flowers and the fleshy bottoms of the leaves on the head of artichoke called brakte. In addition to vitamins $\mathrm{A}$ and $\mathrm{C}$, it is a very rich vegetable in terms of various minerals such as calcium, potassium, iron, manganese and phosphorus. Globe artichoke, which has a very important place in terms of human health as well as its nutritional value, is known to be a beneficial plant for the liver since ancient times. Globe artichoke is widely used in the pharmaceutical industry as it is beneficial for human health. Globe artichoke is one of the oldest medicinal plants that are beneficial for many diseases with many natural antioxidants and pharmacological effects. As a matter of fact, globe artichoke has been reported to be liver-protecting, cholesterol-lowering, anticarcinogenic, diuretic, jaundice and digestive aid with its compounds such as cynarin, luteolin, dicaffeoylquinic acids and flavonoids as well as anti-HIV, antifungal, and antibacterial (Xia et al., 2014; Lattanzio et al., 2009; AbuReidah et al., 2013; Bektaş and Saner, 2013).

The top five countries in globe artichoke production in the world are Italy, Spain, Egypt, Peru and Argentina, respectively. Artichoke is an important export product after citrus and potatoes in Turkish Republic of Nothern Cyprus (NC). The climatic conditions of the country are very suitable for globe artichoke production. Despite this, some years of frost loss restricts the advantage of early production. While the globe artichoke production area in NC was 1469 da in 2006, it reached 5622 da in 2016. In 2016, 66\% of the production areas are Gazimağusa Region, 15\% Güzelyurt Region, 11\% Pier Area and

$51 \mid \mathrm{P}$ a g e

www.iiste.org 
8\% Nicosia Region. 12,099 tons of products were purchased from these production areas in 2016, and the most artichoke production was obtained from the Gazimağusa region with 8.898 tons (Anonymous 2017). Since globe artichoke is a perennial vegetable, globe artichoke plantations can remain in their place for 8 to 10 years (Vural 2008). In areas where globe artichoke cultivation has been carried out for many years, there is a decrease in economic efficiency caused by important plant diseases and seasonal improper climatic conditions. It has been reported by various researchers that some important fungal diseases such as Verticillium wilt (Verticillium dahliae), White mold (Sclerotinia sclerotiorum), Gray mold (Botrytis cinerea), Downy mildew (Bremia lactucae) and Powdery mildew (Leveillula taurica) cause serious problems in the globe artichoke production in the World (Oin et al., 2008; Matos 2009; Doley and Jite, 2012; Bhat and Subbarao, 1999; Larran and et al., 2004; Sherf and Macnab, 1986; Carranza et al., 2001; Agrios 2005). The study was carried out on the presence of economically restricting diseases of the globe artichoke produced extensively in the NC and increasing the complaints of farmers. The aim of our study is to determine fungal disease pathogens that economically limit globe artichoke production in the region.

\section{Materials and Methods}

The main material of the study consisted of samples from plants that show signs of fungal disease in the artichokes cultivated in Gazimağusa, Güzelyurt, İskele, Lefkoşa and Girne between 2014-2016. In the study, 79 infected plants were collected in a sample of 5 county (Bora and Karaca, 1970; Karman 1971). The samples of globe artichoke plants collected were labeled and kept at $+4^{0} \mathrm{C}$ for diagnostic studies of fungal disease. As a result of the diagnostic study, the globe artichoke field, where the disease was diagnosed, was accepted as a dish with that disease and the $\%$ prevalence rates of the disease were calculated (Bora and Karaca, 1970). For this purpose, fungus isolations; Roots, stems, leaves taken from plants with signs of disease were collected on paper bags. 2-3 mm sized plant pieces were cut with a clean scalpel with plant parts, patient and tissues. Afterwards, these parts were kept in a sterile cabinet in a $1 \%$ sodium hypochlorite $(\mathrm{NaOCI})$ solution for 2-3 minutes and surface sterilization was performed. The surface tissue sterilized plant tissue pieces were passed through sterile distilled water twice and the $\mathrm{NaOCI}$ residue was removed and transferred to sterile blotting paper in order to remove excess water in the tissue. The dried pieces were planted in $9.0 \mathrm{~cm}$ Petri dishes containing Potato Dextrose Agar (PDA) medium. Petri dishes were incubated at $24 \pm 1{ }^{\circ} \mathrm{C}$ for 7-10 days for the development of the disease (Çolak et al., 2013). Following the incubation, the isolates were re-insulated and the identification of at least 2 isolates belonging to each district from the morphological and macroscopic basis was made using the diagnostic keys given in the literatüre (Yu 1945; Morgan 1971; Booth 1971; Mordue 1974; Singleton et al., 1992; Mullen 2001; Sarr et al., 2014 ).

\section{Results}

Globe Artichoke is a highly nutritious and highly valuable cultural plant for human health. It was reported that the globe artichoke was improved from the thistle in Sicily (Italy) during the Roman period and spread to other regions by the Arabs in the early middle ages (Bektaş and Saner, 2013). In the Turkish Republic of Northern Cyprus, globe artichoke cultivation is carried out economically in the area of 2,769 da of the Gazimağusa Region, 626 da of the Güzelyurt region, 457 da of the Iskele Region, 329 da of the Lefkoşa Region and 21 da of the Girne Region (Anonymous 2017). The number of fungal isolates (number), diseased area (da) and \% values obtained from the area of globe artichoke cultivation in 444.2 da of these regions are given in Table 1.

Observations and sampling were carried out in the field at 444.2 da, representing a total of 5588 da survey area, where globe artichoke cultivation was made, and $67.10 \%$ of this 258.73 da area was found to be infected by fungal diseases. In the study, soil-borne pathogens in the NC globe artichoke cultivation areas; fungal diseases have been identified in the plant, which cause root, root collar rot, wilt diseases, Sclerotinia sclerotiorum, Botrytis cinerea, Fusarium spp. and Macrophomina phaseolina. As seen in Table 1, the most common fungal disease rate in artichoke cultivated areas was found to be White mold disease caused by Sclerotinia sclerotiorum (Figure1). The highest rate of white mold disease in the region was obtained from Gazimağusa globe artichoke fields with $41.2 \%$, followed by Iskele with $37.5 \%$, Güzelyurt with 34.6\%, Lefkoşa with 33.3\% and Girne with 25\%. Among the fungal pathogens diagnosed in the region, the lowest contaminated field was determined at 2.66 da and Girne county was $100 \%$ contaminated with Fusarium spp. 


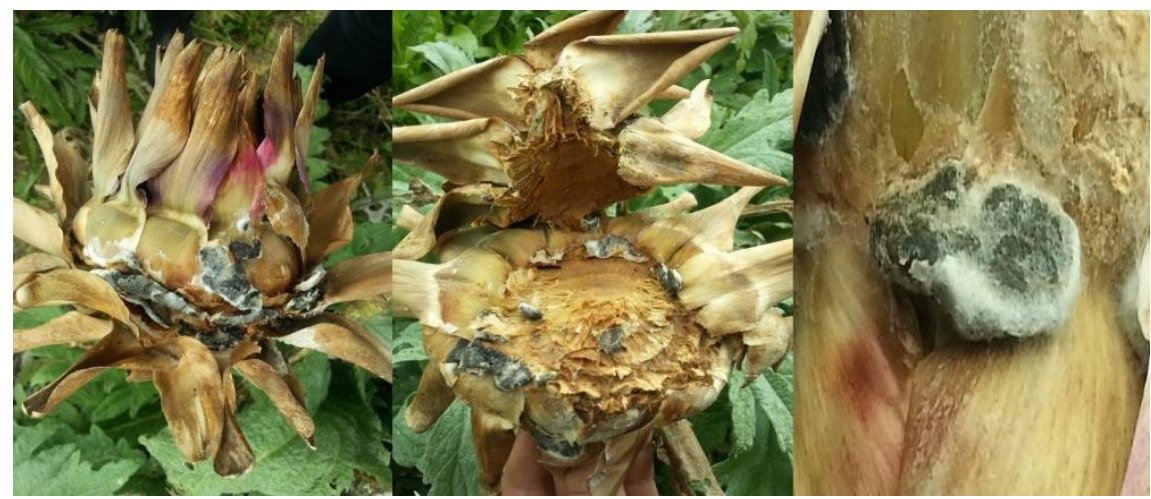

Figure 1. Symptoms of Sclerotinia sclerotiorum in the globe artichoke plant.

Soil-borne pathogens attack the roots of the plants, collar roots and lower parts of the stem, causing these tissues to deteriorate and rot, as well as wilt diseases. It is very difficult to combat such soil-borne diseases. Because these plant pathogens produce various spores and similar structures that are capable of sustaining their existence in soil, plant residues mixed with soil and living root tissues for a long time (Çolak and Biçici, 2013). Since globe artichoke is a perennial vegetable, globe artichoke cultivation areas can be cultivated for at least 7 years. In this context, production in the same plant and field for many years causes an increase in soil-borne diseases. In the study, White mold isease caused by Sclerotinia sclerotiorum, which is seen intensely in NC globe artichoke production areas, is a soil-borne pathogen. The host sequence of the disease pathogen is quite wide, causing root, stem and fruit rot in about 400 plant species. The disease spends the winter as sclerot in the soil or plant residues. It has been noted that the sclerot formed by $S$. sclerotiorum, which is seen intensely in temperate climatic regions, continues to live in the soil for more than 10 years. It has been reported that in crops where the disease is intensely infected, the plant completely dies, and in fields where it is less infected, the plants lose their market value due to losses in the size and weight of the product (Clarkson et al., 2014; Adams and Ayers, 1979; Clarkson et al., 2004; Smolinka and Kowalaka, 2018; Çolak 2019).

In Italy, where globe artichoke production is intense, Marcucci et al. (2010) reported that Sclerotium sclerotium is one of the most important problems in many areas where globe artichoke production is made in the inner parts of Italy. In the control against disease; they found that b-aminobutyric acid (BABA) showed its effect on the formation of resistance in globe artichokes and the accumulation of associated defense compounds. They reported that the use of BABA in early plant stages is a promising approach for control of soil-borne pathogens, such as early infection of S. sclerotiorum, if the study results are confirmed by field tests. In a study by Matos (2009); In Peru, studies have been carried out in in-vitro and greenhouse conditions on the chemical and biological control of White mold disease, which is a problem in globe artichoke production. Copper sulfate, pentahydrate, carbendazim, chlorothalonile, iprodione and boscalid were used chemically in the study. Bacillus subtilis and Trichoderma harzianum and were used as biofungicides. In the study, carbendazim, iprodione and boscalid are among the fungicides in vitro; Bacillus subtilis as biofungicides, has been reported to inhibit the mycelial development of S. sclerotiorum by $100 \%$. In greenhouse studies, biofungicide of boscalid, iprodione, carbendazim and Trichoderma harzianum were found to be effective in White mold (Sclerotium sclerotium) disease.

In NC globe artichoke production areas; It has been determined that the most common fungal pathogen detected after the white rmold disease is Gray mold disease caused by Botrytis cinerea (Çizelge 1). The area with the highest Gray mold disease in the region is Güzelyurt county with $32.58(62 \%)$; this was followed by Gazimağusa with 22.61 (54.83\%), İskele with 18.62 (50\%), Lefkoşa with $5.98(100 \%)$ and Girne with $3.99(42.85 \%)$. Gray mold disease, in which plants were detected, was observed especially in the stem of the plants and just below the head. Gray mold disease caused by Botrytis cinerea is a pathogen that can affect more than 200 plant species that can be seen in all agricultural areas (Williamson et al., 2007). Indeed, in cases where plant tissues injured during cultural procedures are exposed to cool and humid conditions for a long time, the disease is observed more in globe artichoke plants. Botrytis cinerea

53 | P a g e

www.iiste.org 
is more severe after wet, rainy weather periods. It has also been reported that globe artichoke heads are more prone to the formation of Gray mold disease in plants with calcium deficiency (Francois et al.,1991).

Larran et al. (2004), it has been reported that the disease pathogen is gray mold (Botrytis cinerea) with isolation and pathogenicity tests performed in brownish and black mummification parts of diseased plant heads in Argentine globe artichoke areas. In our study, it was observed that the snail population was very high in the Güzelyurt and Gazimağusa regions, where the Gray mold was fastness, in the globe artichoke areas. It was concluded that fungal disease harms the snail's nutrition, especially in the head and stem of the globe artichoke, it enters the tissues, and this may be effective in seeing the disease more widely in these fields. In all areas where NC globe artichoke was produced, it was determined that snail damage was more or less in leaves and fruits. In diagnoses made with snail samples, Helix spp., Helicella spp. and Eobania spp. belongs to the species. This fungus often occupies bracts that have been damaged by insects, snails, frost or other abiotic factors. Thus, infected artichoke bracts start from the outside and turn brown. Characteristic gray growth of Botrytis cinerea develops on the inner surface of the brackets. Globe artichoke production areas; the control for snails and insects also means the indirect control against gray mold disease (Koike and Bari, 2019).

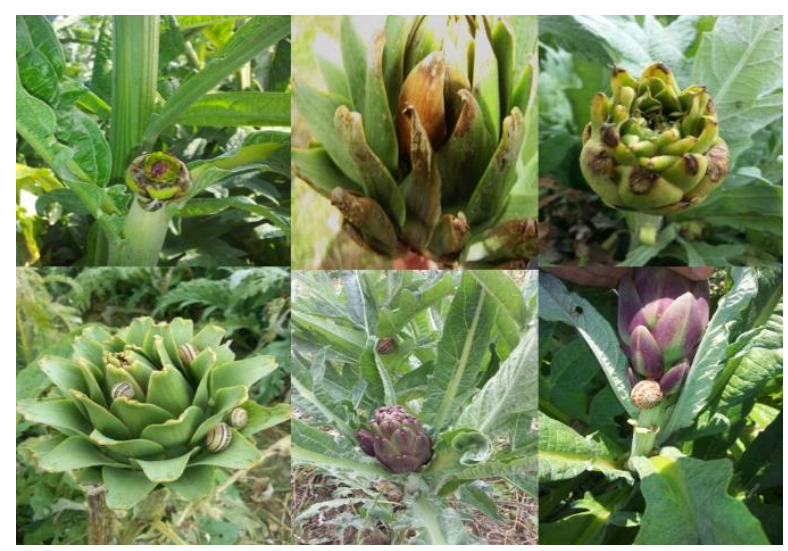

Figure 2. Botrytis cinerea symptoms and snail in globe artichoke plant.

Macrophomina phaseolina (Tassi.) Goid. caused by charcoal root rot disease, it was obtained from Gazimagusa county with a maximum area of 8.69 (41.2\%), followed by Güzelyurt and Lefkoşa county. The disease is a soil-borne fungal disease that has been detected in many products worldwide, of high economic importance, and seen in more than 500 products. Macrophomina phaseolina causes especially in plants under water stress and at high temperatures and causes product loss. Product rotations are not very effective due to the wide host range of fungi. It has been reported that growing plants in good nutritional conditions is the best preventive measure (Doley and Jite, 2012).,

In the study, the least common disease in NC globe artichoke areas compared to other soil-borne diseases was found to have root rot and wilt disease in the plant caused by Fusarium spp. The disease was detected in Güzelyurt county with a maximum area of 15.99. Fusarium spp. (Table1).They are soil-borne diseases, blocking the transmission bundles of the plant, causing wilt and death of the plant over time. Fungus micelles or spores colonize the epidermal tissues of the root throughout the xylem and kill it by blocking the plant's conduction tissue with the toxic chemicals and spores it produces. Soil and environmental conditions, injured plant roots are an important factor in increasing the disease. Cultural measures in the control against disease; excessive nitrogen applications should be avoided in order to obtain more products, soil disinfection, frequent cultivation and excessive irrigation should not be done, and the selection of disease resistant varieties is important (Beckman 1987; Mariano et al., 1994; Caesar et al., 1999). 
Table1. Disease rates of some fungal pathogens in globe artichoke production areas.

\begin{tabular}{|c|c|c|c|c|c|c|}
\hline \multirow[t]{2}{*}{ County } & \multirow[t]{2}{*}{$\begin{array}{c}\text { Fungal disaese } \\
\text { pathogens }\end{array}$} & \multirow{2}{*}{$\begin{array}{c}\text { Isolate } \\
\text { number } \\
\text { number }\end{array}$} & \multirow{2}{*}{$\begin{array}{c}\begin{array}{c}\text { Disease } \\
\text { rate }\end{array} \\
\% \\
\end{array}$} & \multirow{2}{*}{$\begin{array}{c}\text { Surveyed } \\
\text { area } \\
\text { da } \\
\end{array}$} & \multicolumn{2}{|c|}{$\begin{array}{l}\text { Infected area (da) } \\
\text { and percentage }\end{array}$} \\
\hline & & & & & da & $\%$ \\
\hline & Botrytis cinerea & 8 & 30.8 & 52.53 & 32.58 & 62.02 \\
\hline & Fusarium spp. & 6 & 23.0 & 33.25 & 15.99 & 48.09 \\
\hline & S. sclerotiorum & 9 & 34.6 & 41.23 & 23.94 & 58.06 \\
\hline \multirow[t]{4}{*}{ Güzelyurt } & $\begin{array}{l}\text { Macrophomina } \\
\text { phaselonia }\end{array}$ & 3 & 11.5 & 15.96 & 5.98 & 37.46 \\
\hline & Total/Average & 26 & - & 142,97 & 78,49 & 51,41 \\
\hline & Botrytis cinerea & 5 & 31.3 & 37.24 & & 50 \\
\hline & Fusarium spp. & 3 & 18.8 & 15.96 & $\begin{array}{l}18.62 \\
6.65\end{array}$ & 41.7 \\
\hline \multirow{4}{*}{ Ískele } & S. sclerotiorum & 6 & 37.5 & 42.56 & 19.95 & 46.87 \\
\hline & $\begin{array}{l}\text { Macrophomina } \\
\text { phaselonia }\end{array}$ & 2 & 12.5 & 7.98 & 3.32 & 41,60 \\
\hline & Total/Average & 16 & - & 103,74 & 48,54 & 45,04 \\
\hline & Botrytis cinerea & 9 & 26.5 & 41.23 & 22.61 & 54.83 \\
\hline \multirow[t]{6}{*}{ Gazimağusa } & Fusarium spp. & 4 & 11.8 & 21.28 & 11.97 & 56.25 \\
\hline & S. sclerotiorum & 14 & 41.2 & 83.12 & 59.18 & 71.19 \\
\hline & $\begin{array}{l}\text { Macrophomina } \\
\text { phaselonia }\end{array}$ & 7 & 20.6 & 17.29 & 8.69 & 50.26 \\
\hline & Total/Average & 34 & - & 162,92 & 102,45 & 58,133 \\
\hline & Botrytis cinerea & 1 & 33.3 & 5.98 & 5.98 & 100 \\
\hline & Fusarium spp. & - & - & & & \\
\hline \multirow[t]{5}{*}{ Lefkoşa } & S. sclerotiorum & 1 & 33.3 & 7.98 & 7.98 & 100 \\
\hline & $\begin{array}{l}\text { Macrophomina } \\
\text { phaselonia }\end{array}$ & - & & & & \\
\hline & Total/Average & 3 & & 13,96 & 13,96 & 100 \\
\hline & Botrytis cinerea & 1 & 25.0 & 9.31 & 3.99 & 42.85 \\
\hline & Fusarium spp. & 1 & 25.0 & 2.66 & 2.66 & 100 \\
\hline \multirow[t]{3}{*}{ Girne } & S. sclerotiorum & 2 & 50.0 & & 8.64 & 100 \\
\hline & $\begin{array}{l}\text { Macrophomina } \\
\text { phaselonia }\end{array}$ & - & - & $\begin{array}{l}8.64 \\
-\end{array}$ & - & - \\
\hline & Toplam/Average & 4 & & 20,61 & 15,29 & 80,95 \\
\hline \multicolumn{2}{|c|}{ Grand Total/Average } & 79 & & 444.20 & 258.73 & 67.10 \\
\hline
\end{tabular}

\section{Conlusion}

Globe artichoke is a Mediterranean originated and nutritious plant species and is widely used in human nutrition and pharmaceutical industry. Some diseases and pests that restrict NC globe artichoke cultivation decrease the market value in addition to the advantages of earlyness in production. Since fungal diseases are seen intensely in the region, it is determined that the producers do not know the factor and are insufficient in both cultural and integrated control. In the study, it was concluded that one of the most important reasons for the disease to spread rapidly and to be seen every year is that globe artichoke locations are made in the same field for a long time. In addition, in the observations made during the survey study, it was determined that the diseased plants were not destroyed by dismantling and the disease pathogens spread rapidly with the increase of humidity and temperature due to the fact that frequent planting was provided with sufficient ventilation in the field.

In NC production areas; to prevent the entry and prevalence of fungal disease types, passing the plant materials at the health checks at the ports and using the internal-external quarantine effectively will play 
an important role in the eradication of these diseases. In this context, in order to prevent diseases and pests from entering the country and to control existing diseases; It is important to use resistant varieties and to implement integrated control methods with vector insects that play an important role in the spread of some plant diseases. However, in order to ensure a long-term control and an effective biological control especially in soil-borne diseases such as Sclerotium sclerotium disease pathogen, which is found in the region; It is important to use crop rotation, resistant cultivars, solarization (soil disinfection) and taking all cultural measures together. Therefore, it has been revealed that an integrated approach using multiple control measures can provide sustainable control of plant fungal pathogens. In the success of such a disease strategy, it is important to choose agriculture and crop management practices that reduce the accumulation of plant disease pathogen inoculum and the risk of disease spread.

\section{Acknowledgements}

In this study, "Disease, Pest and Weeds Towards the in the Quarantine and Certification Basis Determination in Turkish Republic of Northern Cyprus " is a part of the project. In this context, Author would like to thank the General Directorate of Agricultural Research and Policies/Turkey and the Cyprus Department of Agriculture for their contributions. Also the Author would like to thank Deda Büyüköztürk (entomolog) for their contributions in this study.

\section{References}

Abu-Reidah, I.M., Arraez-Roman D., Segura-Carretero, A., \& Fernandez-Gutierrez, A. (2013). Extensive characterisation of bioactive phenolic constituents from globe artichoke (Cynara scolymus L.) by Hplc-Dad-Esı-Qtof-Ms, Food Chemistry, 141(3), 2269-2277.

Adams, P.B., \& Ayers W.A. (1979). Ecology of Sclerotinia species. Phytopathology, 69: (8), 896898.

Agrios, G. N., (2005). Plant Pathology, Fifth Edition. Elsevier Academic Press, USA.

Anonymous (2017) Kuzey Kıbrıs Türk Cumhuriyeti Tarım Ve Doğal Kaynaklar Bakanlı̆ğ Tarım Master Planı Raporu, p:271.

Bektaş, K. Z., \& Saner, G. (2013). Artichoke Production and Marketing in Turkey. Journal of Agricultural Faculty of Uludag University, 27:1, 115-128.

Beckman, C.H. (1987). The Nature of Wilt Diseases of Plants. St. Paul, Minnesota: American Phytopathological Society Press, 175.

Bhat, R. G., Subbarao, K. V., \& Bari, M. A. (1999). First report of Verticillium dahliae causing artichoke wilt in California, Plant Disease, 83, (8), 782.

Bhat, R.G., \& Subbarao, K.V. (1999). First Report of Verticillium dahliae Causing Artichoke Wilt in California. Plant disease, 83(8): 782.

Booth, C. (1971). Fusarium a laboratory guide to the identification of the major species. C.M.I. Kew surrey, pp.58. England.

Bora, T., \& Karaca, I. (1970). Kültür Bitkilerinde Hastalığın ve Zararın Ölçülmesi, Ege Üniversitesi Ziraat Fak. Yardımcı Ders Kitab1, No:167, Ege Üniversitesi Matbaası, Bornova, $43 \mathrm{~s}$.

Caesar, A.J., Campobasso, G., \& Terragitti, G. (1999). Effects of European and U.S. Strains of Fusarium spp. Pathogenic to Leafy Spurge on North American Grasses and Cultivated Species. Biological Control 15, 130-136.

Carranza, M., Aliipi, H.E., \& Larran, S. (2001). First Report of Artichoke Downy Mildew Caused by Bremia lactucae in Argentina. Plant Disease 85(4):446-446. DOI: 10.1094/PDIS.2001.85.4.446D 
Clarkson, J.P., Phelps, K., Whipps, J.M., Young, C.S., Smith, J.A., \& Watling, M. (2004). Forecasting Sclerotinia disease on lettuce: toward developing a prediction model for carpogenic germination of sclerotia. Phytopathology 94:268-279

Clarkson, J. P., Fawcett, L., Anthony, S. G., \& Young, C. (2014). A model for Sclerotinia sclerotiorum infection and disease development in lettuce, based on the effects of temperature, relative humidity and ascospore density. PLoS One 9(4): e94049.

Çolak, A.A. (2019). Effect of Coniothyrium minitans and Trichoderma harzianum in the biological control of white mold disease (Sclerotinia sclerotiorum) in lettuce (Lactuca sativa L.). Applied Ecology And Environmental Research 17(6):15687-15701.

Çolak, A., \& Biçici, M. (2013). Integrated Disease Management of Fusarium Crown and Root Rot of Greenhouse-Grown Tomato in Eastern Mediterranean Region of Turkey. Journal of Agricultural Sciences 19 (2013) 89-100.

Del Río, L. E., Bradley, C. A., \& Johnson B. L. (2005). First report of white mold caused by Sclerotinia sclerotiorum on echium (Echium vulgare), Plant Disease, 89, (6), 684.

Doley, K., \& Jite, P.K. (2012). In-Vitro Efficacy of Trichoderma viride Against Sclerotium rolfsii and Macrophomina phaseolina. Notulae Scientia Biologicae, 4(4):39-44

Francois, L.E., Donovan T.J., \& Maas E.V. (1991). Calcium deficiency of artichoke buds in relation to salinity. Hortscience, 26(5):549-553.

Karman, M. (1971). Bitki Koruma Araştırmalarında Genel Bilgiler, Denemelerin Kuruluşu ve Değerlendirilme Esasları, Bölge Zir. M.A. Enst. İzmir. Tar. Bak. Zir. Müc. ve Kor. Genel Müd. Yayınları,1971.

Koike, S.T., \& Bari, M. A. (2019). UC Pest Management Guidelines: Artichoke, Gray Mold (Botrytis cinerea), UC ANR Publication 3434, http://ipm.ucanr.edu/PMG.

Larran, S., Ronco, L., Carranza, M. R., \& Zuccaro, M. (2004). Grey mould of the globe artichoke in Argentina. Australasian Plant Pathology, 33 (3): 461.

Marcucci, E., Aleandri, M. P., Chilosi, G., \& Magro, P. (2010). Induced resistance by ßaminobutyric acid in artichoke against white mould caused by Sclerotinia sclerotiorum. Journal of Phytopathology, 158, (10), 659-667.

Mariano, R. L. R., Reis, A., \& Michereff, S. J. (1994). Diseases caused by fungi on artichoke, lettuce, chicory, strawberries and okra. Informe Agropecuário (Belo Horizonte) 17(182), 13-16.

Matos, L. S. T. (2009). Biological and chemical control of Sclerotinia sclerotiorum (Lib.) De Bary in artichoke (Cynara scolymus L.), thesis for the degree of master, National Agrarian University Graduate School of Specialization in plant pathology, Lima, Peru. Abstract. http://repositorio.lamolina.edu.pe/handle/123456789/39.

Mordue, J. E. (1974). CMI Descriptions of Pathogenic Fungi and Bacteria. No. 410. CAB International, Wallingford, U.K.

Morgan, D. T. (1971). Numerical taxonomic studis of the genus Botrytis. Trans. Br. Mycol., Soc., 56(3): 327-335.

Mullen, J. (2001). The Plant Health Instructor. Southern blight, Southern stem blight, White mold. The Plant Health Instructor. DOI: 10.1094/PHI-I-2001-0104-01 
Nermien H.S., Thabet A., Markeb A.A., Sayed D.M., \& El-Maali N.A. (2019), In vitro- exploration of fungal endophytes of Egyptian Cynara scolymus L. (artichoke) and investigation of some their bioactive potentials, Global NEST Journal, 21(3), 297-309.

Qin, Q.M., Vallad, G. E., \& Subbarao, K. V. (2008). Characterization of Verticillium dahliae and V. tricorpus isolates from lettuce and artichoke. Plant Dis. 92:69-77.

Sarr, M.P., Ndiaye, M'baye, Johannes, Z., Groenewald, Z.G., \& Pedro W. C. (2014). Genetic diversity in Macrophomina phaseolina, the causal agent of charcoal rot. Phytopathologia Mediterranea: 53 (2), 250-268.

Sherf, A. F., \& MacNab, A. A. (1986). Vegatable Diseases and Their Control. Secon edition, Printed in The United States of America ISBN: 0-471-05860-2, p:30-31.

Singleton, L.L., Mihail J.D., \& Rush, C.M. (1992). Methods for Research on Soilborne Phytopathogenic Fungi. APS press, pp.266. St. Paul, Minnesota.U.S.A.

Smolinska, U., \& Kowalska, B. (2018). Biological control of the soil-borne fungal pathogen Sclerotinia sclerotiorum, a review. Journal of Plant Pathology, 100:1-12.

Sneh, B., Burpee, L., \& Ogoshi, A. (1991). Identification of Rhizoctonia species. APS press St. Paul, M.N., U.S.

Williamson, B., Tudzynski, P., \& Tudzynski, B. (2007). Botrytis cinerea: The cause of grey mould disease. Moleculer Plant Pathology 8(5):561-80.

Xia, N., Pautz A., Wollscheid, U., Reifenberg, G., Forstermann, U., \& Li, H. (2014). Artichoke, cynarin and cyanidin downregulate the expression of inducible nitric oxide synthase in human coronary smooth muscle cells, Molecules, 19(3), 3654-3668. doi: 10.3390/molecules19033654.

Vural, H. (2008). Enginar yetiştiriciliği. http://www.gencziraat.com/Bahce-Bitkileri/EnginarYetistiriciligi.html.

Yu, T. F. (1945). The red-spot disease of broad beans (Vicia faba L.) caused by Botrytis fabae Sardina in China. Phytopathology 35:945-954. 